\title{
Pathways to Internationalize Brazilian Journals of Psychology
}

\section{Caminhos para Internacionalizar as Revistas de Psicologia no Brasil}

\author{
Estêvão C. Gamba ${ }^{\mathrm{a}}$, Abel Laerte Packer ${ }^{\mathrm{b}}$ \& Rogerio Meneghini ${ }^{\mathrm{b}}$ \\ ${ }^{a}$ Universidade Federal de São Paulo, São Paulo, SP, Brazil \& ${ }^{b}$ Programa SciELO/Fundação de Apoio à \\ Universidade Federal de São Paulo, São Paulo, SP, Brazil
}

\begin{abstract}
The science of psychology has been developing in the country of Brazil over the last 50 years. Nonetheless, most of the science in this field is published only in Brazilian journals. Overall, Brazil has yet to share its science with the international community. The potential to internationalize the science generated by Brazilian psychologists exists, though. One way would be to scale up the publication of Brazilian psychologists in international journals. Another way would be to internationalize the existing Brazilian journals. With regard to the latter possibility, a metric analysis of scientometrics databases suggests that the reasons for the low impact of articles published in Brazilian journals are manifold, but the low performance is mainly explained by the scarce employment of the lingua franca-English language-in the articles. This article discusses the role that SciELO, a Brazilian scientific publisher, has played in indexing and assisting the best Brazilian psychology journals in raising their horizons, in terms of internationalizing their output, while at the same time serving as an instrument of promotion for national studies of psychology within the country of Brazil. Keywords: psychology, journals, internationalization, SciELO, international English.
\end{abstract}

\begin{abstract}
Resumo
A Psicologia no Brasil é uma área científica cujo desenvolvimento remonta aos últimos 50 anos. A maior parte do conhecimento produzido por seus cientistas é publicada em periódicos nacionais. Por conseguinte, tal condição tem imposto barreiras na disseminação deste conhecimento para comunidades internacionais. O potencial para internacionalização da ciência produzida por pesquisadores brasileiros da psicologia encontra dois desafios: um seria levar suas publicações a revistas internacionais; o outro seria internacionalizar as revistas brasileiras de psicologia em geral restritas às fronteiras nacionais. Sobre o segundo desafio, a análise da base de dados da cientometria mostra que as razões para o baixo impacto dos artigos publicados em periódicos nacionais são múltiplas, mas é explicada principalmente pelo escasso número de artigos em língua inglesa. Discute-se o papel que o SciELO, um Publisher científico brasileiro, na ampliação dos horizontes dos melhores periódicos brasileiros, promovendo maior inserção internacional, e na sua afirmação como um importante instrumento nacional para estudos de psicologia.

Palavras-chave: psicologia, revistas, internacionalização, SciELO, Inglês internacional.
\end{abstract}

The internationalization of Brazil’s scientific journals is a major challenge faced by the nation's research community. This challenge is of particular impact to such areas as human and agriculture sciences, in which researchers rely heavily upon journals published by national institutions to promote their articles. The area of psychology has become particularly sensitive to this challenge due to its notable growth over the last decades as an academic discipline and a professional field. The first courses of psychology and the profession

Correspondence concerning this article should be addressed to Rogerio Meneghini, Programa SciELO/FAPESP, São Paulo, SP, Brazil; e-mail: rogerio. meneghini@scielo.org of psychologist were first recognized in Brazil in 1962. Since that year, the number of psychology courses taught and the number of psychological professionals has increased more than any field within the country. In 2015 there are about 400 undergraduate courses, 70 postgraduate courses (47 granting $\mathrm{PhDs}$ ) and 216,000 professionals in activity. From the sole perspective of the number of psychologists in the work force, Brazil stands as a leader in the world. Although it has been reported that psychology in Brazil is strongly oriented towards applications (Nunes, 1993), the academic growth of psychology has been outstanding. For example, in 2013 Brazil was the twelfth highest producer of psychology articles covered by Scopus database and Web of Science 
Gamba, E. C., Packer, A. L., Meneghini, R. (2015). Pathways to the Internationalization of Psychology Journals in Brazil.

Core database. Some say that psychology in Brazil is experiencing a golden age, probably comparable to that which took place in the 1940s and 1950s in the United States (Hutz, McCarthy, \& Gomes, 2004).

Brazilian psychology articles are communicated mainly through journals edited and published by national institutions, which, on one side, captures aspects of the Brazilian specificities but, on the other, poses barriers to its dissemination, especially to the international community. The present study briefly examines three interrelated topics of Brazilian psychology: (1) the growth and visibility of psychology articles authored by Brazilian authors; (2) the psychology journals of Brazil and their impact on the national and international scientific communities; and (3) the coverage and performance of psychology journals in Brazil as measured by three international multidisciplinary databases (SciELO, Scopus and Web of Science). While some of these topics have been previously examined, such as the improvement of strategies for the production of knowledge in specific areas of psychology (Tourinho $\&$ Bastos, 2010), and the upgrading of the assessment procedures of national journals to international standards (Meneghini, 2012; Packer, 2014), to the best of our knowledge, these topics have never been examined as a constellation; i.e., as interacting components of a group.

\section{Method, Results and Discussion}

This study makes use of international bibliographic scientific information sources: Scientific Electronic Library Online (SciELO), Scimago Journal and Country Rank (Scimago), with data extracted from Scopus database, and Scopus and Web of Science All Database Collection (WoS-AD). The aim was to extract the key indicators on the scientific production of Brazil and evaluate the progress and performance of its journals and its likelihood to become more international. The WoS-AD covers, besides the Core Collection of WoS (WoS CC), journals of the Scientific Electronic Library Online Citation Index database (SciELO
CI) as well as other databases. The SciELO CI covers select journals from nine Latin American countries, plus South Africa, Spain and Portugal.

The results and discussions are presented individually for each of the proposed topics related to the internationalization of Brazilian psychology journals: growth and visibility of research articles by authors with Brazilian affiliation, the impact of these journals, and their presence on the international indexes.

\section{Growth and Visibility of Articles}

Over the period 2004-2013, according to Scimago and the WoS CC databases, the progression of scientific publications of Brazil in the area of psychology in relation to the world more than doubled. According to the Scimago database 2014 edition, the number of Brazilian psychology publications leaped from 136 to 1,032 articles per year, which corresponds respectively to a $0.41 \%$ and $1.59 \%$ share of worldwide publications (Table 1). Within the Latin American and Caribbean markets, Brazilian psychology publications increased from $32 \%$ to $52 \%$, respectively. This leap was due in part to an increase in the number of articles produced by Brazilian psychologists combined with the privileged inclusion of Brazilian journals in the indexes. This is particularly true for Scopus that promoted a sharp increase in the number of journals of Brazil. As Table 1 shows, during 2004 and 2005, no Brazilian psychology journals were indexed in Scopus. However, in 2007, the number of Brazilian psychology journals indexed in Scopus jumped to 6 , with $298(54 \%)$ of the 555 articles by Brazilian authors published in a total of 122 journals. This dominant presence of Brazilian journals, covering about $60 \%$ of the Brazilian articles on psychology, has remained throughout the last 7 years with a steady increase in the number of journals. In 2013, Brazilian affiliated articles on psychology were published in 159 journals, 16 of which originated in Brazil. Because of the dominance of Brazilian psychology journals, articles in Portuguese, the native language of Brazil, prevail with low international collaboration.

Table 1

Distribution and Trends of Brazilian Psychology Articles: 2004-2013

\begin{tabular}{|c|c|c|c|c|c|c|c|}
\hline Year & $\begin{array}{l}\text { World Rank } \\
\text { by Articles }\end{array}$ & $\begin{array}{l}\text { Articles } \\
\qquad(N)\end{array}$ & $\begin{array}{l}\text { \% Latin American and } \\
\text { Caribbean Articles }\end{array}$ & $\begin{array}{l}\% \text { World } \\
\text { Articles }\end{array}$ & $\begin{array}{l}\text { Journals } \\
(N)\end{array}$ & $\begin{array}{c}\% \text { Brazilian } \\
\text { Psych } \\
\text { Journals }\end{array}$ & $\begin{array}{c}\% \text { Articles in } \\
\text { Brazilian Psych } \\
\text { Journals }\end{array}$ \\
\hline 2004 & 25 & 136 & 31.70 & 0.41 & 65 & - & - \\
\hline 2005 & 19 & 183 & 36.90 & 0.57 & 76 & - & - \\
\hline 2006 & 14 & 457 & 54.15 & 1.19 & 93 & - & - \\
\hline 2007 & 11 & 555 & 53.01 & 1.39 & 122 & 4.92 & 53.69 \\
\hline 2008 & 10 & 680 & 51.36 & 1.63 & 134 & 5.22 & 53.38 \\
\hline 2009 & 11 & 731 & 49.19 & 1.50 & 122 & 7.38 & 62.11 \\
\hline 2010 & 11 & 931 & 54.25 & 1.71 & 135 & 7.41 & 58.75 \\
\hline 2011 & 10 & 922 & 50.85 & 1.54 & 153 & 7.84 & 66.59 \\
\hline 2012 & 10 & 1,036 & 53.26 & 1.70 & 159 & 8.81 & 65.35 \\
\hline 2013 & 12 & 1,032 & 51.81 & 1.59 & 159 & 10.06 & 68.60 \\
\hline
\end{tabular}

Note. Data Source: Scimago and Scopus indexing, 2014; Psych, psychology. 
Using Scimago 2011 country ranking and covering the thirty most productive countries in psychology, the lowest-ranking articles, as measured by citations per article in 2013, are from "developing or emerging countries" (Table 2). Except for China, all of these countries' rankings are below the median. Again, among the lowest-ranking articles are those from developing countries that rely heavily on journals published nationally, most in non-English language. We may add that underlying bias could also be considered in the list of reasons for the lack of recognition of the scientific contributions from developing countries (Marusic \&
Marusic, 1999; Salager-Meyer, 2008; Sumathipala, Siribaddana, \& Patel, 2004).

It is widely accepted that citations per article should not be taken as a direct measurement of the relevance/ quality of scientific articles, since, as reasoned above, citations of articles is a parameter very much dependent on such aspects of the article as: language, nationality, author's networks, international collaboration, journal visibility and delayed credit. As a consequence, international ranking and comparisons of journals, although an important index of research performance, should be taken with a grain of salt.

Table 2

Ranking of the 30 Most Productive Countries in the Field of Psychology

\begin{tabular}{|c|c|c|}
\hline Country & Articles Published in 2011 & Citations per Article in 2013 \\
\hline United States & 21,536 & 4.89 \\
\hline United Kingdom & 5,722 & 4.81 \\
\hline Germany & 3,304 & 4.97 \\
\hline Canada & 3,164 & 5.10 \\
\hline Australia & 2,353 & 4.58 \\
\hline Netherlands & 2,247 & 6.36 \\
\hline France & 2,194 & 2.67 \\
\hline Spain & 1,705 & 3.28 \\
\hline Italy & 1,615 & 4.60 \\
\hline Brazil & 922 & 1.63 \\
\hline Japan & 912 & 2.59 \\
\hline Iran & 849 & 0.60 \\
\hline Belgium & 838 & 5.05 \\
\hline Switzerland & 818 & 4.97 \\
\hline Turkey & 779 & 0.97 \\
\hline Israel & 778 & 4.29 \\
\hline China & 751 & 4.32 \\
\hline Sweden & 658 & 5.02 \\
\hline Taiwan & 528 & 3.71 \\
\hline New Zealand & 516 & 3.86 \\
\hline Norway & 490 & 5.09 \\
\hline Finland & 422 & 5.13 \\
\hline Portugal & 414 & 2.73 \\
\hline Austria & 378 & 4.03 \\
\hline South Korea & 348 & 3.65 \\
\hline Poland & 341 & 1.95 \\
\hline Mexico & 329 & 1.59 \\
\hline South Africa & 329 & 2.60 \\
\hline India & 324 & 2.31 \\
\hline Hong Kong & 322 & 4.23 \\
\hline
\end{tabular}

Note. Data Source: Scimago. 
Gamba, E. C., Packer, A. L., Meneghini, R. (2015). Pathways to the Internationalization of Psychology Journals in Brazil.

\section{Brazilian Psychology Journals}

The number of Brazilian journals has experienced a remarkable growth in the last decades - about 150 (55\%) of SciELO journals indexed started publishing in the last 25 years. This growth is mainly due to increased pressure on publication output from Brazilian postgraduate courses from the Coordination for the Improvement of Higher Education Personnel (CAPES), a federal agency of the Ministry of Education. Currently, the number of Brazilian psychology journals approaches 50 titles, with most of them available online in open access through the Periódicos Electrônicos em Psicologia (PEPSIC) Portal (Instituto de Psicologia da USP, 2014). Among these, 14 journals are indexed in the WoS-All Databases (Table 3 ), from which only one is indexed in both the WoS Core Collection and SciELO CI. As is typical within the Brazilian social sciences, the majority of these articles are published in Portuguese. Recently however, Englishlanguage publication is increasing in the journals of Brazil. SciELO has noted a rise in English-language publication from $42 \%$ (2010) to $54 \%$ (2013) in recent years. This trend is also present in the human-sciences-related journals, but the number of English-language articles is still very low.

The majority of citations received by Brazilian psychology journals come from Brazil, and other Portuguese- or Spanish-speaking countries. This is in contrast to citations received by Brazilian natural sciences journals, most of which originate from USA, China, England and Germany. We predict this trend will be observed in Brazilian psychology journals as the prominent language shifts from Portuguese to English.

\section{Coverage of Brazilian Journals in International Databases (SciELO, Scopus and Web of Science)}

The number of Brazilian journals from all subject areas ranked by CAPES through its Qualis system is around 6,000 (Carvalho Neto, 2013). Of these 6,000, only $5 \%$ are considered to be of international level. The Qualis rank provides a stable system to rank articles and journals; it defines the prestige of the journals based on past performance. Of the 6,000 journals ranked by Qualis, approximately 1,000 have been submitted to SciELO for indexing. Roughly one of every three or four journals submitted has been accepted by SciELO. In the area of psychology, 48 journals have been submitted to SciELO, from which 14 have been accepted so far. The PEPSIC portal provides a comprehensive indexing of Brazilian and other Latin American journals. PEPSIC follows up the performance of journals whose indicators are used in the SciELO indexing evaluation.

Table 3

Distribution and Performance of Brazilian Psychology Articles in Brazilian Psychology Journals: Language and Citations

\begin{tabular}{|c|c|c|c|c|c|c|c|c|c|}
\hline \multirow[t]{2}{*}{ Journal } & \multicolumn{3}{|c|}{ Articles: 2010-2011 a } & \multicolumn{3}{|c|}{ Citations: $2012-2013^{b}$} & \multicolumn{3}{|c|}{ Cites/Article: 2012-2013b } \\
\hline & All & English & Portuguese & All & English & Portuguese & All & English & Portuguese \\
\hline $\begin{array}{l}\text { Psicologia: Reflexão e } \\
\text { Crítica }\end{array}$ & 167 & 21 & 143 & 121 & 17 & 102 & 0.725 & 0.810 & 0.713 \\
\hline $\begin{array}{l}\text { Psicologia Teoria e } \\
\text { Pesquisa }\end{array}$ & 161 & 2 & 157 & 85 & 1 & 84 & 0.528 & 0.500 & 0.535 \\
\hline $\begin{array}{l}\text { Estudos de Psicologia } \\
\text { (Campinas) }\end{array}$ & 113 & 3 & 107 & 57 & 2 & 55 & 0.504 & 0.667 & 0.514 \\
\hline Psico-USF & 91 & - & 90 & 44 & - & 44 & 0.484 & - & 0.489 \\
\hline Paidéia (Ribeirão Preto) & 97 & - & 96 & 39 & & 39 & 0.402 & - & 0.406 \\
\hline Psicologia em Estudo & 157 & 2 & 151 & 58 & 1 & 56 & 0.369 & 0.500 & 0.371 \\
\hline $\begin{array}{l}\text { Estudos de Psicologia } \\
\text { (Natal) }\end{array}$ & 85 & 1 & 72 & 28 & 0 & 28 & 0.329 & 0.000 & 0.389 \\
\hline $\begin{array}{l}\text { Psicologia Ciência e } \\
\text { Profissão }\end{array}$ & 145 & - & 144 & 45 & - & 44 & 0.310 & - & 0.306 \\
\hline Psicologia \& Sociedade & 163 & - & 152 & 40 & - & 37 & 0.245 & - & 0.243 \\
\hline $\begin{array}{l}\text { Fractal : Revista de } \\
\text { Psicologia }\end{array}$ & 100 & - & 90 & 18 & - & 18 & 0.180 & - & 0.200 \\
\hline Psicologia USP & 96 & - & 93 & 15 & - & 15 & 0.156 & - & 0.161 \\
\hline $\begin{array}{l}\text { Psicologia Escolar e } \\
\text { Educacional }\end{array}$ & 79 & - & 73 & 8 & - & 9 & 0.101 & - & 0.123 \\
\hline Psicologia Clínica & 89 & - & 89 & 9 & - & 9 & 0.101 & - & 0.101 \\
\hline $\begin{array}{l}\text { Àgora: Estudos em } \\
\text { Teoria Psic. }\end{array}$ & 44 & - & 44 & 3 & - & 4 & 0.068 & - & 0.091 \\
\hline Total & 1,587 & 29 & 1,501 & 570 & 21 & 544 & 0.359 & 0.724 & 0.362 \\
\hline
\end{tabular}

Note. ${ }^{a}$ Data source: SciELO Citation Index; ${ }^{b}$ Data source: Journals of the WoS, All Databases. 
Evaluating journals is not a mathematical exercise. For instance, the comparison between SciELO and SCOPUS coverage of psychology journals results in an overlap of titles of only $50 \%$. Based on citation counts, journals perform similarly in both databases, though one would expect higher values in Scopus as it covers 100 times more journals than SciELO. This similarity is due to the fact that the citations received are predominantly domestic, from other SciELO Journals.

Table 4

Performance of Brazilian Psychology Journals: Citations per Article in 2012 for Articles Published in 2010 and 2011

\begin{tabular}{|c|c|c|}
\hline \multirow[t]{2}{*}{ Journal } & \multicolumn{2}{|c|}{ 2-Year Citations per Article } \\
\hline & Scopus & SciELO \\
\hline Agora: Estudos em Teoria Psicanalítica & 0.03 & 0.00 \\
\hline Arquivos Brasileiros de Psicologia & 0.05 & \\
\hline Estudos de Psicologia (Campinas) & 0.07 & 0.05 \\
\hline Estudos de Psicologia (Natal) & & 0.03 \\
\hline Fractal Revista de Psicologia & & 0.10 \\
\hline Paideia Ribeirão Preto & 0.13 & 0.30 \\
\hline Psicologia Ciência e Profissão & & 0.15 \\
\hline Psicologia Clinica & 0.02 & 0.00 \\
\hline Psicologia e Sociedade & 0.11 & 0.06 \\
\hline Psicologia em Estudo & 0.16 & 0.22 \\
\hline Psicologia Escolar e Educacional & & 0.10 \\
\hline Psicologia USP & 0.05 & 0.05 \\
\hline Psicologia: Reflexão e Critica & 0.31 & 0.29 \\
\hline Psicologia: Teoria e Pesquisa & 0.21 & 0.26 \\
\hline Psico-USF & & 0.23 \\
\hline Revista Latinoamericana de Psicopatologia Fundamental & 0.11 & 0.13 \\
\hline Tempo Psicanalitico & 0.05 & \\
\hline
\end{tabular}

Note. Data sources: Scopus and SciELO.

Table 5

Performance of Top Brazilian Psychology Journals: 2010-2012

\begin{tabular}{ccc}
\hline CNPq Ranking & Journals & Indexed in SciELO \\
\hline 1 & Psicologia: Reflexão e Crítica & YES \\
2 & Psicologia: Teoria e Pesquisa & YES \\
3 & Avaliação Psicológica & YES \\
4 & Estudos de Psicologia (Campinas) & YES \\
5 & Estudos de Psicologia (Natal) & YES \\
6 & Psicologia USP & YES \\
7 & Psico USF & NO \\
8 & Interamerican Journal of Psychology & YES \\
9 & Psicologia e Sociedade & NO \\
10 & Psico (PUCRS) & NO \\
11 & Temas em Psicologia (Ribeirão Preto) & YES \\
12 & Paidéia (USP-RP) & NO \\
13 & Aletheia (ULBRA) & NO \\
14 & Interação (Curitiba) & NO \\
16 & Psicologia Ciência e Profissão (Brasilia) & NO \\
18 & Psicologia Escolar e Educacional, Campinas & YES
\end{tabular}

Note. CNPq, National Council of Scientific and Technological Development; this list includes journals ranked 1A (highest ranking) by $\mathrm{CNPq}$. 
Gamba, E. C., Packer, A. L., Meneghini, R. (2015). Pathways to the Internationalization of Psychology Journals in Brazil.

From a different angle, when we look at where the top Brazilian scholars (ranked $1 \mathrm{~A}$ by $\mathrm{CNPq}^{1}$ ) choose to submit their manuscripts, we see that only 10 of 14 SciELO psychology journals were considered (Table 5). Certainly, the procedure of evaluating a journal follows given policies and criteria. It is not an erratic exercise, but is not exempt of discrepancy either.

\section{Final Considerations}

In principle, we might consider that the impact of research articles, as measured by citations received, is closely related to their quality, influence and/or relevance. However, there are factors that give sway to this concept of impact in many circumstances, especially when research is of national or regional interest or orientation. Within these special circumstances, a major factor is language. Another one is the prestige of the journal that publishes findings of nationally-oriented research. As to the language factor, we must consider that countries with a large population of scholars, like Brazil, in which English is not the native language, face a double challenge. First, researchers must learn to communicate their science in English with an increasingly demanding accuracy. Secondly, they cannot let their native language be overlooked in scientific texts. Consider, for example, the dozens of undergraduate and postgraduate psychology courses that are taught in Portuguese in Brazil. The native language may absorb new scientific concepts expressed by English words, but, inevitably, the bulk of scientific words and expressions, which certainly will be borne in English, will have to be translated into the native language semantic. We may have to face a double effort, as compared to countries in which English is the native language (Meneghini \& Packer, 2007). But in a global open minded world we may gain some benefits from that. After all, physiological studies have shown that speaking two (or more) languages is a great asset to our cognitive capacity (Diaz, 1983).

As to the prestige of the journals, again it seems difficult to separate this attribute from the use of English. To maintain an equilibrium between language and prestige of the journals, the best and, we think, unique way is to make the journals bilingual and as such to progressively internationalize the editorial board and authors' affiliation. It may be a double effort, but it has the potential for a double benefit.

\section{References}

Carvalho Neto, S. (2013). Scientific serials in the Capes Qualis and the Brazilian open access journals. PKP Scholarly Publishing Conference 2013. Retrieved from http://pkp.sfu. ca/pkp2013/paper/view/366

CNPq investigators are a select group of scholars of different areas of knowledge, elected and ranked by committees which take into consideration their original and effective contribution to science. Investigators are ranked at one of five levels: 1A, 1B, 1C, 1D, 2. CNPq stands for National Council of Scientific and Technological Development.
Diaz, R. M. (1983). Thought and two languages: The impact of bilingualism on cognitive development. Review of Research in Education, 10, 23-54. doi:10.2307/1167134

Hutz, C., McCarthy, S., \& Gomes, W. (2004). Psychology in Brazil: The road behind and the road ahead. In M. J. Stevens \& D.Wedding (Eds.), Handbook of International Psychology (pp. 151-168). New York: Brunner-Routledge.

Instituto de Psicologia da USP (2014). Periódicos eletrônicos em Psicologia (PEPSIC). Retrieved from http://pepsic. bvsalud.org/

Marusic, A., \& Marusic, M. (1999). Small scientific journals from small countries: Breaking from a vicious circle of inadequacy. Croatian Medical Journal, 40,(4), 508-514. Retrieved from http://neuron.mefst.hr/docs/CMJ/issues/1999/40/4/10554353.pdf

Meneghini, R. (2012). Emerging journals: The benefits of and challenges for publishing scientific journals in and by emerging countries. EMBO Reports, 13(2), 106-108. doi:10.1038/embor.2011.252

Meneghini, R., \& Packer, A. (2007). Is there science beyond English? Initiatives to increase the quality and visibility of non-English publications might help to break down language barriers in scientific communication. EMBO Reports, 8(2), 112-116. doi:10.1038/sj.embor.7400906

Nunes, T. (1993). Psychology in Latin America: the Case of Brazil. Psychology \& Developing Societies, 5(3), 123-133. doi:10.1177/097133369300500202

Packer, A.L. (2014). The emergence of journals of Brazil and scenarios for their future. Educação e Pesquisa, 40(2), 301323. doi:10.1590/S1517-97022014061860

Salager-Meyer, F. (2008). Scientific publishing in developing countries: Challenges for the future. Journal of English for Academic Purposes, 7(2), 121-132. doi:10.1016/j. jeap.2008.03.009

SCImago (2007). SJR — SCImago Journal \& Country Rank. Retrieved from http://www.scimagojr.com

Sumathipala, A., Siribaddana, S., \& Patel, V. (2004). Underrepresentation of developing countries in the research literature: Ethical issues arising from a survey of five leading medical journals. BMC Medical Ethics, 5(5), 1-6. doi:10.1186/1472-6939-5-5

Tourinho, E. Z., \& Bastos, A. V. B. (2010). Desafios da pós-graduação em Psicologia no Brasil. Psicologia: Reflexão e Crítica, 23(1), 35-46. doi:10.1590/S010279722010000400005
Received: Octuber 22, 2014 Reviewed: January 31, 2015 Accepted: March 01, 2015 